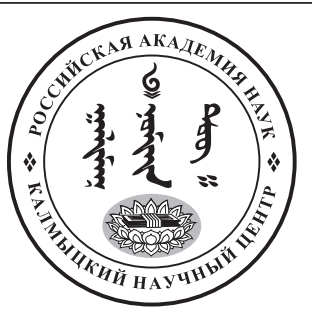

Published in the Russian Federation

Oriental Studies (Previous Name: Bulletin of the Kalmyk Institute

for Humanities of the Russian Academy of Sciences)

Has been issued as a journal since 2008

ISSN: 2619-0990; E-ISSN: 2619-1008

Vol. 13, Is. 3, pp. 696-713, 2020

DOI: $10.22162 / 2619-0990-2020-49-3-696-713$

Journal homepage: https://kigiran.elpub.ru

УДК 81-23

DOI: $10.22162 / 2619-0990-2020-49-3-696-713$

\title{
Новые результаты в генеалогической классификации тюркских диалектов («случаи с аффрикатами»)
}

Анна Владимировна Дьюбо ${ }^{1}$ Лидия Фатиховна Абубакирова ${ }^{2}$, Зухра Казимовна Айбазова Марк Михайлович Зиминн, Евгения Владимировна Коровина Олег Алексеевич Мудрак, Евгения Алексеевна Ренковская ${ }^{8}$, Александр Владиславович Савельев ${ }^{9}$, Олег Ришатович Хисамовв ${ }^{10}$, Александр Владимирович Шаровв ${ }^{11}$, Александра Валерьевна Шеймович ${ }^{12}$

${ }^{1}$ Институт языкознания РАН (д. 1, стр. 1, Большой Кисловский пер., 125009 Москва, Российская Федерация); Высшая школа экономики (д. 20, ул. Мясницкая, 101000 Москва, Российская Федерация); Томский государственный университет, лаборатория лингвистической антропологии (д. 33, просп. Ленина, 634050 Томск, Российская Федерация)

член-корреспондент РАН, доктор филологических наук, профессор, заведующая отделом уралоалтайских языков

iD 0000-0002-6077-7183. E-mail: adybo@iling-ran.ru

2 Томский государственный университет, лаборатория лингвистической антропологии (д. 33, просп. Ленина, 634050 Томск, Российская Федерация)

кандидат филологических наук, доцент, старший научный сотрудник

iD 0000-0002-1530-5590. E-mail: lidiya_bspu@mail.ru

${ }^{3}$ Институт языкознания РАН (д. 1, стр. 1, Большой Кисловский пер., 125009 Москва, Российская Федерация)

младший научный сотрудник

(iD) 0000-0002-3621-0654. E-mail: zuhra@iling-ran.ru

${ }^{4}$ Институт языкознания РАН (д. 1, стр. 1, Большой Кисловский пер., 125009 Москва, Российская Федерация)

лаборант-исследователь

iD 0000-0002-2043-9868. E-mail: ung.ofelia@gmail.com

${ }^{5}$ Институт языкознания РАН (д. 1, стр. 1, Большой Кисловский пер., 125009 Москва, Российская Федерация)

младший научный сотрудник

iD 0000-0002-3072-585X. E-mail: evkorovina@iling-ran.ru

${ }^{6}$ Институт языкознания РАН (д. 1, стр. 1, Большой Кисловский пер., 125009 Москва, Российская Федерация); Томский государственный университет, лаборатория лингвистической антропологии 
(д. 33, просп. Ленина, 634050 Томск, Российская Федерация)

младший научный сотрудник

iD 0000-0002-5634-6583. E-mail: vmaltseva@iling-ran.ru

${ }^{7}$ Институт языкознания РАН (д. 1, стр. 1, Большой Кисловский пер., 125009 Москва, Российская Федерация)

доктор филологических наук, профессор, главный научный сотрудник

iD 0000-0002-8553-7063. E-mail: omudrak@iling-ran.ru

${ }^{8}$ Институт языкознания РАН (д. 1, стр. 1, Большой Кисловский пер., 125009 Москва, Российская Федерация)

младший научный сотрудник

iD 0000-0003-1944-0746. E-mail: erenkovskaya@iling-ran.ru

9 Институт языкознания РАН (д. 1, стр. 1, Большой Кисловский пер., 125009 Москва, Российская Федерация)

кандидат филологических наук, научный сотрудник

iD 0000-0002-8343-2057.E-mail: a.savelyev@iling-ran.ru

${ }^{10}$ Институт языка, литературы и искусства им. Г. Ибрагимова АН РТ (д. 12, ул. Карла Маркса, 420111 Казань, Российская Федерация)

кандидат филологических наук, зам. директора

iD 0000-0002-3776-8035. E-mail: ohisamov@mail.ru

${ }^{11}$ Институт языкознания РАН (д. 1, стр. 1, Большой Кисловский пер., 125009 Москва, Российская Федерация)

лаборант-исследователь

iD 0000-0001-9803-9330. E-mail: ghauasha@gmail.com

${ }^{12}$ Институт языкознания РАН (д. 1, стр. 1, Большой Кисловский пер., 125009 Москва, Российская Федерация)

младший научный сотрудник

iD 0000-0001-6363-114X. E-mail: asheimovich@yandex.ru

(C) КалмНЦ РАН, 2020

( С Дыбо А. В., Абубакирова Л. Ф., Айбазова 3. К., Зимин М. М., Коровина Е. В., Мальцева В. С., Мудрак О. А., Ренковская Е. А., Савельев А. В., Хисамов О. Р., Шаров А. В., Шеймович А. В. 2020

Аннотация. Цель статьи - продемонстрировать некоторые новые результаты, полученные при работе над составлением Диалектологического атласа тюркских языков России. При подготовке атласа авторский коллектив, кроме уже имеющихся опубликованных и архивных источников, использует целенаправленный полевой сбор материала по специально составленным анкетам, ориентированным на известные факты из истории тюркских языков. Материал собирается в виде звуковых файлов, которые затем обрабатываются и обращаются в электронные звуковые словари, доступные в сети Internet. Фонетические материалы анализируются при помощи аудирования, программ акустического фонетического анализа и связываются с электронной этимологической базой данных по тюркским языкам. Оказывается, что сбор материалов, основанный на исторически ориентированных диалектологических анкетах, помогает получить данные, опираясь на которые можно уточнить научные представления о генеалогической классификации диалектов, путях их расхождения и конвергенции, архаических и инновационных явлениях в обследуемых ареалах. На примере трех тюркских ареалов демонстрируются диалекто-дифференцирующие явления в среднеязычных консонантизмах. Для хакасско-шорско-чулымского ареала выясняется последовательность действия правил, определивших расхождение этих идиомов. Оказалось, в частности, что два среднечулымских говора, мелетский и тутальский, не восходят к общему пра-идиому, тутальский говор представляет собой архаический вариант мрасско-шорского, а мелетский непосредственно связан с кызыльским диалектом хакасского языка. Выделен также еще один хакасский диалект, не имеющий специфической близости с другими. Для карачаево-балкарского ареала окончательно доказана вторичность «дзокания» по отношению к более существенной изоглоссе потери 
смычки начальной аффрикатой. Для татарско-башкирского ареала определены три основных диалекто-дифференцирующих типа рефлексации *j- и предполагается хронология их распределения в ареале.

Ключевые слова: тюркские языки, диалектология, хакасский язык, шорский язык, чулымско-тюркский язык, карачаево-балкарский язык, татарский язык, башкирский язык, ареалогия, сравнительно-историческая фонетика

Благодарность. Работа выполнена по проекту РНФ № 18-18-00501 «Создание электронного диалектологического атласа тюркских языков России». Авторы выражают благодарность также всем информантам и коллегам, помогавшим при сборе диалектологического материала.

Для цитирования: Дыбо А. В., Абубакирова Л. Ф., Айбазова З. К., Зимин М. М., Коровина Е. В., Мальцева В. С., Мудрак О. А., Ренковская Е. А., Савельев А. В., Хисамов О. Р., Шаров А. В., Шеймович А. В. Новые результаты в генеалогической классификации тюркских диалектов («случаи с аффрикатами») // Oriental Studies. 2020. T. 13. № 3. C. 696-713. DOI: 10.22162/2619-0990-2020-49-3-696-713

UDC 81-23

DOI: $10.22162 / 2619-0990-2020-49-3-696-713$

\section{Some New Results in the Genealogical Classification of Turkic Dialects: 'Cases of Affricates'}

Anna V. Dybo ${ }^{1}$, Lidia F. Abubakirova ${ }^{2}$ Zukhra K. Aibazova ${ }^{3}$. Oleg R. Hisamov ${ }^{4}$, Evgeniya V. Korovina ${ }^{5}$, Vera S. Maltseva ${ }^{6}$, Oleg A. Mudrak, Evgeniya A. Renkovskaya ${ }^{8}$, Alexander V. Savelyev ${ }^{9}$, Aleksandr V. Sharov ${ }^{10}$, Alexandra V. Sheymovich ${ }^{11}$, Mark M. Zimin ${ }^{12}$

${ }^{1}$ Institute of Linguistics of the RAS (1/1, Bolshoi Kislovsky Lane, Moscow 125009, Russian Federation); Higher School of Economics (20, Myasnitskaya St., Moscow 101000, Russian Federation); Tomsk State University, Laboratory of Linguistic Anthropology (33, Lenin Ave., Tomsk 634050, Russian Federation) Corresponding Member of the RAS, Dr. Sc. (Philology), Professor, Head of Ural-Altaic Department iD 0000-0002-6077-7183. E-mail: adybo@iling-ran.ru

${ }^{2}$ Tomsk State University, Laboratory of Linguistic Anthropology (33, Lenin Ave., Tomsk 634050, Russian Federation)

Cand. Sc. (Philology), Associate Professor, Senior Research Associate

iD 0000-0002-1530-5590. E-mail: lidiya_bspu@mail.ru

${ }^{3}$ Institute of Linguistics of the RAS (1/1, Bolshoi Kislovsky Lane, Moscow 125009, Russian Federation) Junior Research Associate

iD 0000-0002-3621-0654. E-mail: zuhra@iling-ran.ru

${ }^{4}$ Ibragimov Institute of Language, Literature and Arts (12, Karl Marx St., Kazan 420111, Russian Federation)

Cand. Sc. (Philology), Deputy Director

iD 0000-0002-2043-9868. E-mail: ung.ofelia@gmail.com

${ }^{5}$ Institute of Linguistics of the RAS (1/1, Bolshoi Kislovsky Lane, Moscow 125009, Russian Federation) Junior Research Associate

iD 0000-0002-3072-585X. E-mail: evkorovina@iling-ran.ru

${ }^{6}$ Institute of Linguistics of the RAS (1/1, Bolshoi Kislovsky Lane, Moscow 125009, Russian Federation); Tomsk State University, Laboratory of Linguistic Anthropology (33, Lenin Ave., Tomsk 634050, Russian Federation)

Junior Research Associate

iD 0000-0002-5634-6583. E-mail: vmaltseva@iling-ran.ru

${ }^{7}$ Institute of Linguistics of the RAS (1/1, Bolshoi Kislovsky Lane, Moscow 125009, Russian Federation) Dr. Sc. (Philology), Professor, Chief Research Associate 
0000-0002-8553-7063. E-mail: omudrak@iling-ran.ru

${ }^{8}$ Institute of Linguistics of the RAS (1/1, Bolshoi Kislovsky Lane, Moscow 125009, Russian Federation) Junior Research Associate

iD 0000-0003-1944-0746. E-mail: erenkovskaya@iling-ran.ru

${ }^{9}$ Institute of Linguistics of the RAS (1/1, Bolshoi Kislovsky Lane, Moscow 125009, Russian Federation) Cand. Sc. (Philology), Research Associate

iD 0000-0002-8343-2057. E-mail: a.savelyev@iling-ran.ru

${ }^{10}$ Institute of Linguistics of the RAS (1/1, Bolshoi Kislovsky Lane, Moscow 125009, Russian Federation) Research Laboratory Assistant

iD 0000-0002-3776-8035. E-mail: ohisamov@mail.ru

${ }^{11}$ Institute of Linguistics of the RAS (1/1, Bolshoi Kislovsky Lane, Moscow 125009, Russian Federation) Junior Research Associate

iD 0000-0001-9803-9330. E-mail: ghauasha@gmail.com

${ }^{12}$ Institute of Linguistics of the RAS (1/1, Bolshoi Kislovsky Lane, Moscow 125009, Russian Federation) Research Laboratory Assistant

iD 0000-0001-6363-114X. E-mail: asheimovich@yandex.ru

(C) KalmSC RAS, 2020

(C) Dybo A. V., Abubakirova L. F., Aibazova Z. K., Hisamov O. R., Korovina E. V., Malceva V. S., Mudrak O. A., Renkovskaya E. A., Savelyev A. V., Sharov A. V., Sheimovich A. V., Zimin M. M., 2020

Abstract. Introduction. As is well known, the three Turkic dialectal continua - Tatar-Bashkir, Shor-Khakass-Chulym, and Karachay-Balkar ones - have developed quite distinctive reflexes of proto-Turkic palatal *j- and *č-, *-č(-). While compiling the Dialectological Atlas of Russia's Turkic Languages, the authors were able to compose exact isoglosses of $* j$ - and $*_{c}$ change in members of the mentioned continua, which made it also possible to partially reevaluate genetic clusterization on the basis of this data. Materials and Methods. Apart from the available publications and archival sources on the three areas in question, the analysis is based on the authors' extensive field work that involves the use of a set of lexical questionnaires compiled in accordance with known aspects of the Turkic linguistic history. The source recordings for every speaker were turned into idiolectal audio-dictionaries and are linked to an electronic etymological database of the Turkic languages, each elicitation analyzed both with the comprehension method and the software for experimental phonetics. Results. As it turns out, this methodology of field work and post-analysis provides information crucial for detailed linguistic clusterization of dialectal continua in particular and any dialectal system in general. Traditionally, subtle problems of divergence and convergence, problems of archaic and innovative phenomena receive their solutions. The results are as follows. Palatal $*_{j}$ - and $*_{c}$ in the languages of the Khakass-Shor-Chulym group have changed by a strict series of rules none of which could be simultaneous, nor could follow each other in a different order. Thus, the two Middle Chulym dialects - Melet and Tutal ones — prove to lack an immediate linguistic ancestor, the Tutal 'dialect' is an archaic version of Mrassu Shor, while Melet is closely related to Kyzyl Khakass. Reflexes of $*_{\mathrm{j}-}$ and $*_{\breve{c}}$ are also principal isoglosses for a previously undocumented Khakass dialect, which does not have any specific affinity with Saghai, Kyzyl and Kachin dialects. Areal analysis of KarachayBalkar shows that $\mathrm{dz}<$ proto-Turkic $*_{\mathrm{j}}$ - is a secondary development, while, on the other hand, it is finally proven that reflexes $*_{\mathrm{j}-}>\mathrm{dz} \sim \mathrm{dz}$ and $*_{\mathrm{j}-}>_{\mathrm{z} \sim \mathrm{Z}}$ form a more significant isogloss. And for the Tatar-Bashkir dialectal continuum, there were identified three main types of proto-Turkic $*_{\mathrm{j}}$ reflexation; a chronology for these three types intermixing during the early period of the continuum is also proposed.

Keywords: Turkic languages, dialectology, Khakass language, Shor language, Chulym-Turkic language, Karachay-Balkar language, Tatar language, Bashkir language, areal linguistics, dialectal continuum, historical phonetics

Acknowledgements. The reported study was funded by Russian Science Foundation, project no. 1818-00501 'Digital Dialectological Atlas of Russia's Turkic Languages'. The authors are also grateful to all informants and colleagues who assisted in collecting dialectological materials. 
For citation: Dybo A. V., Abubakirova L. F., Aibazova Z. K., Hisamov O. R., Korovina E. V., Maltseva V. S., Mudrak O. A., Renkovskaya E. A., Savelyev A. V., Sharov A. V., Sheimovich A. V., Zimin M. M. Some New Results in the Genealogical Classification of Turkic Dialects: 'Cases of Affricates’. Oriental Studies. 2020. Vol. 13(3): 696-713. (In Russ.). DOI: 10.22162/2619-0990-202049-3-696-713

\section{है}

\section{Введение}

В процессе составления тома Сравнительно-исторической грамматики тюркских языков «Региональные реконструкции» [СИГТЯ 2002] стало очевидно, что, во-первых, подробная и тщательная реконструкция пратюркского состояния, наследующих ему дочерних состояний и происходивших в них изменений, приведших к современной картине и/или отраженных в письменных памятниках тюркских языков, невозможна без обращения к диалектным данным. Во-вторых, выяснилось, что, хотя тюркская диалектология является хорошо развитой дисциплиной, имеющей большую научную традицию, все же состояние собранных и проанализированных материалов далеко от полноты и системности. По ряду важнейших для истории языков параметров у нас просто отсутствуют данные. Поэтому в течение 15 лет наша исследовательская группа занимается, так сказать, ревитализацией проекта диалектологического атласа тюркских языков, амбициозной задачей, некогда поставленной Советским Комитетом тюркологов, приведшей к созданию нескольких региональных атласов, но в целом и так и не завершенной. Сейчас эта работа проводится на обновленных методологических основаниях; подробнее историю вопроса и теоретические предпосылки работы см. в [Дыбо и др. 2020а].

Из уже полученных к настоящему моменту результатов наиболее интересны обнаруженные локальные изменения в генеалогической и ареальной классификации внутри отдельных групп тюркских языков. Ниже мы рассматриваем три примера, связанных с уточнением в группах реконструкций в системе консонантизма, в зоне аффрикат и фрикативных.

1. Генеалогическое членение и ареальные отношения в диалектной системе тюркских 3-языков Южной Сибири, то есть хакасского, мрасского диалекта шор- ского и среднечулымского диалекта чулымско-тюркского языка. Здесь не обсуждаются з-языки Китая, фуюйско-киргизский и сарыг-югурский, поскольку по ним у нас отсутствуют фонетические материалы.

К. Шёниг классифицировал эти идиомы как часть «Border Turkic group» (пограничной тюркской группы), ошибочно исключив из «енисейско-тюркских» чулымский, шорский диалект хакасского и мрасский диалект шорского [Schönig 1997: 124]1․

В действительности ситуация такова: так называемый нижний диалект чулымского определенно отражает $*_{-} \delta$ - $>j$, а так называемый средний диалект чулымского *- $\delta$ - > z; так называемые шорский диалект хакасского и мрасский диалект шорского также демонстрируют $*_{-} \delta$ - $>z$, а так называемый кондомский диалект шорского отражает *- $\delta$ - $>j$, принадлежа в реальности к алтайской группе идиомов. В [СИГТЯ 2002: 476-599] перечисленные выше 3-идиомы правильно объединены и включены в «кыргызскую» группу тюркских языков. Как уже понятно из изложенного, границы генеалогических групп в случае этих языков не соответствуют общепринятым и социолингвистически обоснованным границам между «диалектными группами языков».

В настоящее время ряд идиомов, ранее описанных и классифицированных диалектологами, доступен наблюдению только в остаточном состоянии - у небольшого количества лиц старшей возрастной группы. Дру-

${ }^{1}$ О мрасском диалекте шорского ср. также [Waibel 2006]; надо сказать, что не все параметры, по которым там рассматриваются отношения шорского диалекта хакасского с «хакасским», выделены точно, поскольку хакасский берется только как письменный литературный язык, вне связи с реальным произношением и диалектными вариантами. Более подробно об инновационных и архаических изоглоссах, выделяющих шорский диалект хакасского, см. в готовящемся томе [Дыбо и др. 2020б]. 
гие носители владеют локальными вариантами языка в слабой степени, переходя либо на литературный хакасский (в Хакасии), либо на русский. Тем не менее и их речь позволяет обнаружить - в отклонениях от нормы, которые в этом случае должны квалифицироваться как переключение или смешение кодов - ряд важных для восстановления картины генеалогических отношений между диалектами особенностей, часть из которых ранее в классификации не учитывалась.

В 2011-2019 гг. нами предпринят был ряд экспедиций к носителям идиомов данной группы в Южной Сибириㄹ. Обследовано 108 населенных пунктов. Материал записей — звуковые файлы в формате .wav, они постепенно нарезаются, транскрибируются в фонетической транскрипции, приближенной к IPA, снабжаются спектрограммами, сделанными в программе PRAAT, переводами и тюркскими праформами в системе TURCBET (пояснения к пратюркской реконструкции, использованной в ней, см. в [Дыбо 2007: 13-63]) и загружаются в системy Lingvodoc (http://lingvodoc.ispras.ru/) $)^{3}$.

Наиболее заметный признак, выделяющий рассматриваемую группу языков, это совпадение в их общем праязыке трех общетюркских (Common Turkic, т. е. ветвь тюркских языков, разделившуюся после отделения булгарской ветви) фонем: *- $\delta(-)>$ $*_{-z}(-), *_{s}>*_{s}$, $*_{-} \check{r}(-)>*_{-z}(-)$ все совпали в одну фонему $s / z$ (с позиционным распределением, т. е. звонким аллофоном, выступающим в интервокальной позиции). ПТ *-خ(-) $>\mathrm{OT}$ *-̌̌(-) в общем праязыке z-группы coхраняется как $\check{s} / \check{z}$ : Ср.:

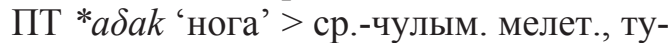
тал., шор. Мр. azáq, хак. шор. (Матур), саг.,

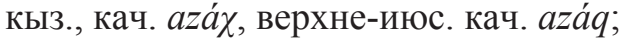

${ }^{2}$ В основной массе представленный ниже среднечулымский материал собран В. М. Лемской и А. В. Савельевым, мрасский шорский А. В. Дыбо, Г. В. Косточаковым, В. С. Мальцевой, Д. М. Токмашевым, А. В. Шеймович; материал с территории Хакасии - А. В. Дыбо, Е. В. Коровиной, А. С. Крыловой, В. С. Мальцевой, С. Л. Николаевым, Е. А. Ренковской, Э. В. Султрековой, Е. Б. Чекменевой, А. В.Шеймович.

3 Материалы полевых диалектологических записей, использованные в статье, выложены на сайтах: http://lingvodoc.ispras.ru/; https://dialects. altaica.ru/.
ПТ *sal- 'класть' > ср.-чулым. мелет., тутал., шор. Мр., хак. шор. (Матур), саг., кыз., кач., верхне-июс. кач. sal 'положи!';

ПТ *bas- 'давить' > ср.-чулым. мелет., тутал., шор. Мр., хак. шор. (Матур), саг., кыз., кач. , верхне-июс. кач. pas 'дави!'; pázip 'давить-Conv';

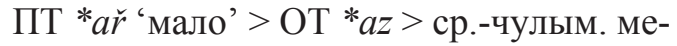
лет., тутал., шор. Мр. as 'мало’; az-óq 'мало-Ass', хак. шор. (Матур), саг., кыз., кач. as 'мало'; az-ó $\chi$ 'мало-Ass', верхне-июс. кач. as 'мало'; az-óq 'мало-Ass';

OT *aš > cр.-чулым. тутал., шор. Мр., хак. шор. (Матур) af 'ячмень', áz-i 'его/ее ячмень'; ср.-чулым. мелет., саг., кыз., кач. , верхне-июс. кач. as 'зерно'; $a ́ z-\dot{t}$ 'его/ее зерно'.

Как известно, для успешного построения генеалогического древа группы идиомов и выяснения их распределения по подгруппам (subgrouping) необходимо рассмотреть не просто объединяющие часть этих идиомов общие инновации. Надежный узел генеалогического древа мы получаем в следующем случае: во всех языках-потомках рассматриваемой группы представлен ряд единиц-потомков праязыковых единиц, которые подверглись сначала одинаковому действию одной группы диахронических процессов, а потом разнонаправленному действию другой группы исторических процессов. В случае рассмотрения фонетических процессов это должны быть морфемы-потомки праязыковых морфем, звуковые оболочки которых показывают результаты воздействия минимум двух правил звуковых переходов, из которых одно правило воздействовало на звуковые оболочки морфем всех языков-потомков, а другое воздействовало на звуковые оболочки морфем только части языков-потомков. В этом случае мы вынуждены будем ввести узел генеалогического древа, в котором праязык разделяется на два праязыка более низкого уровня; из одного произошли те языки, где второе правило действовало, из другого - где не действовало. См. [Дыбо 2007: 12; Ringe \& Eska 2013: 259-262]. Таким образом, для классификации идиомов имеет смысл рассмотреть группу правил, в которой можно выявить относительную хронологию процессов.

Пучок фонетических переходов, который хорошо демонстрирует относительную 
хронологию процессов, в рассматриваемой группе: процессы изменения среднеязычных согласных $\left(* j-, *^{2} \check{c}, *_{-} \check{s}(-)\right)$.

Пример установления относительной хронологии на этой группе правил:

если в современном языке мы видим, чTо:

А. $* \check{c}$ - перешел в $s-$,

Б $*_{j}$ - перешел в $\check{c}$-,

то совершенно определенно А произошло раньше Б,

поскольку иначе результат Б совпал бы c *̌́-, и на него бы подействовал А,

и в языке-потомке рефлексы $* \check{c}$ - не отличались бы от рефлексов *j-.

Рассмотрим материал.

1. Тутальский говор среднечулымского языка - идиом с минимумом переходов от общего состояния системы пра-з-языка. Тутальский говор рассмотрен на материале словарных списков (два 110-словных списка с контекстами, от двух разных информантов, http://lingvodoc.ispras.ru/ dictionary/226/3/perspective/226/4/view и http://lingvodoc.ispras.ru/dictionary/220/4/ perspective/220/5/view).

Звуковые переходы:

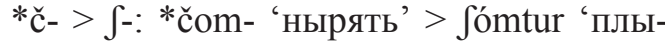
вет', *čik- 'выходить'> јіq 'выходи';

*č > (t)6/d: *agač 'дерево’ > авá(t)6 (VMG), aৎá(t)6, Poss3 aSádłi (VDT); *ič- 'to drink' > *i(t)6 'пей'; *uč- 'to fly' > utє 'лети'; *kičük-geč > kэtcé:tc 'маленький'; *jijč-ge > tcick', toitckæcłík 'тонкий (о плоских объектах)'.

Ассимиляция начального фрикативного перед *č: *sa:č ‘волосы’ > t6a6, Poss3 t6á:dłi, *čo:čka 'свинья' > t6оєьá. Очевидно, этот переход произошел после перехода *č- > $\int-$.

$*_{\mathrm{j}-}>$ t6-: *jer 'земля' > t6عr, *jej 'ешь'

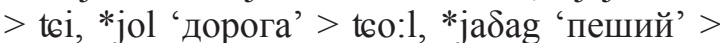
tcazás, *jüz ' 100 ' > t6ys.

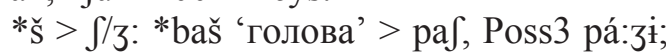
*diš 'зуб' > tIf, *kuš 'птица' > quf, *jakiš-i

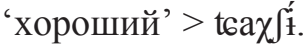

2. Мрасский диалект шорского языка и шорский диалект хакасского языка по этому параметру представляют единство:

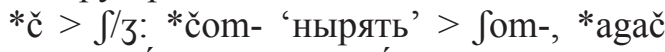
'дерево' >

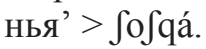
Jázə.

Ассимиляция: *sa:č 'волосы' > $\Lambda \int$, Poss 3 *j- > t $\int-:$ *jo:1 'дорога' > t $\int \mathrm{l}$, *jer 'земля'

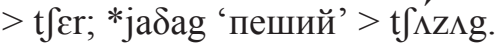

* š > f/3: *baš 'голова' > p $\Lambda$, Poss3 pázə;

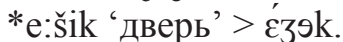

3. Кызыльский диалект хакасского языка распространен сейчас в нескольких населенных пунктах на севере Хакасии; обследован также один населенный пункт в Красноярском крае. Кроме того, кызыльский материал известен по публикации [Joki $1953]^{4}$. В этой работе А. Йоки опубликовал небольшой словарик, собранный от неназванного им военнопленного-кызыльца. Когда мы работали с информантами по кызыльскому языку, мы собрали, в частности, три реплики словарика А. Йоки. Обсуждение упомянутых у А. Йоки кызыльских топонимов с нашим информантом, знатоком кызыльской микротопонимики М. М. Табаткиным позволяет локализовать говор информанта А. Йоки неподалеку от Саралы (скорее всего, с. Агаскыр, ныне нежилое, но у нас было несколько информантов, родившихся и живших там, а позднее переселившихся в другие сёла). Рефлексы в словаре А. Йоки также совпадают с этим говором кызыльского диалекта.

*č- > s-; $\int-/ \int$ (*čik- 'выходить' > si $\chi$-;

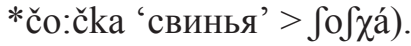

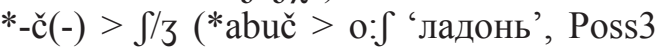
$0: 3 i$.

Ассимиляция: *s- > ${ }^{-} / *_{\text {č }}>\rho$ : $*_{\text {sa:č }}$

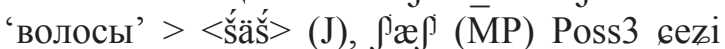
(Т), ९æz $z^{\mathrm{j}}$ (У), <щяжің> 'твои волосы' (АТ),

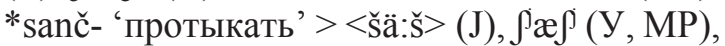
6ezege (Т), <шяжіпскем> 'проткнула' (АТ),

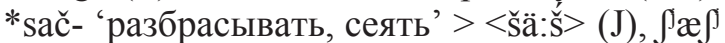
(Т, МР). Очевидно, здесь мы имеем дело со сложным переходом, а) спонтанным развитием $* \check{c}>\rho$, б) ассимиляцией начального s-; и в) упереднением гласной между двумя

4 Другие имеющиеся публикации кызыльского материала [Доможаков 1948; Патачакова 1995; Сунчугашев, Чебочакова 2013] демонстрируют, по видимости, несколько отличающуюся картину, но, поскольку они не используют общезначимых способов записи фонетики, а наши собственные материалы примерно с той же территории, они не показывают значимых отличий от записей А. Йоки, выполненных в чрезвычайно точной традиционной финно-угроведческой транскрипции, то мы относим различия на счет условности кириллических транскрипций этих авторов. 
палатализованными согласными. Ср. аналогичное развитие *seš- 'развязывать' > $е \rho$ (T), которое может объясняться тем, что в переднерядном контексте выступил палатализованный аллофон $\int$, поэтому начальный s- дал также палатализованный фрикативный, и на такое сочетание не продействовало правило перехода $* \check{s}>\mathrm{s}$.

При этом *ja:-с̌Ak 'лук' (общее для ареала образование с уменьшительным суффиксом), включающий морфемную грани-

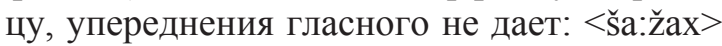
(J), saze $\chi(T$, ББ). fol);

*j- > J- (*jil 'год' > fil; *jo:1 'дорога' >

*š > s/z (*baš 'голова' > pas, Poss3 pázi; *e:šük > ézjik 'ворота').

Новый ассимилятивный процесс, дающий у А. Йоки слегка беспорядочные рефлексы, у наших информантов четкое распределение: ‘̌- любого происхождения > s- /_s/z любого происхождения, если между ними узкий гласный:

\section{А. Йоки:}

с ассимиляцией $*$ ја:z-KI $><$ sasyi $>$ 'весна', *jazuk $><$ sazi $\chi>$ 'грех', *jiסlek $><$ sestäk $>$ 'ягода', *ji $\delta><$ sis 'запах $>$ ';

без ассимиляции *jạztuk $><$ šasti $\chi>$ 'по-

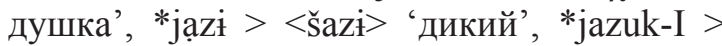
$<$ šazìi > 'мучение', *jüz-dUk > < š̈üstük> 'перстень', *јa:š > < šas> 'мокрый', *ja:š-1Ik

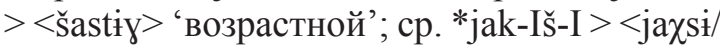
ša sì > 'хороший'.

Современные информанты:

с ассимиляцией $\mathrm{s}^{j} \mathrm{Ys}^{\mathrm{i} t u k}(\mathrm{~T}), \mathrm{s}^{\mathrm{j}} \mathrm{Ys}^{\mathrm{j}} \mathrm{tyk}$ (MP) 'перстень', *jüz > s j Ys (T) '100'; s'istek (MP),

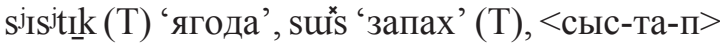
‘чует' (АТ), *jǐš- > <сыс> (АТ) 'тереть';

без ассимиляции sas $\chi \mathrm{w}^{\star}$, 'весна' (T), sazư⿱ $\chi$ 'грех, беда' (T), šas $\chi \dot{i}$ 'грех' (MP), s3stu $\chi$ (T), <шастых> (АТ) 'подушка', sazu

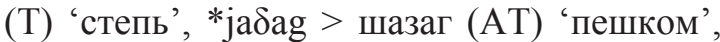

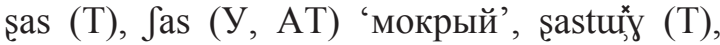
fastiy (У, АТ) 'возрастной'.

Вероятно, результат такой же ассимиляции при узком гласном: ${ }^{*} \mathrm{~s}->\mathrm{s} / *_{\mathrm{s}}>\mathrm{s} / \mathrm{z}$ : *si:š- > sis- (Joki), <cic паған> 'распухла' (AT).

4. Мелетский говор среднечулымского языка

*č- > s-; t6- / (t)6 (*čik- 'выходить'> sәq, *čom- 'нырять' > som-; *čo:с̌ka 'свинья'> t606qá t606xá).

$$
\text { *-с̌(-) > 6/z (*ič- 'пить'> í-). }
$$

Ассимиляция, аналогичная кызыльской: *s- > (t)6- /_*č > 6/z: *sa: ̌́ 'волосы' > (t)6a6, Poss3 t6azə; *sanč- 'протыкать'> 6а:6-, *sač'разбрасывать, сеять'>6а:6, ср. *seš- 'развязывать'> t6e:6-).

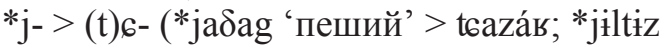
'звезда' > (t)6əltəs, *jüz '100'> (t)6üs);

*š > s/z (*baš 'голова' > pas, Poss3 pazi, *siš 'чирей' > sis).

5. Качинский диалект хакасского языка

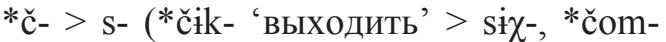

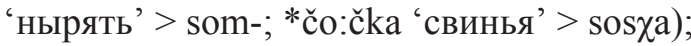

*-с̌(-) > s/z; 6/_I (*agač 'дерево' > акаs, Poss1 авасіm; *sa:č 'волосы' > sas, Poss1 жæ6-im; *ič- 'пить' > is 'пей', Conv i6-ip). Cp. ассимиляцию начального *s- в 6æ6-im.

*j -> 6- (*jẹl 'ветер'> 6ili ; *jẹr 'земля'> cir; *jo:1 'дорога' > 6ol);

* ̌s > s/z (*baš ‘голова'> pas, Poss3 pazi).

6. Староиюсский говор качинского диалекта отличается в данном случае от более южных качинских говоров сохранением аффрикатного характера мягкой аффрикаты, переходящей южнее в фрикативный:

*č- > s- (*čik- 'выходить'> siq-, *čom'нырять' > som-; *čo:с̌ka 'свинья'> sosqa);

*-с̌(-) > s; t6/_I (*agač 'дерево' > акаs, Poss3 aваtсim; *sa:č 'волосы' > sas, Poss3 t6æt6im; *ič- 'пить' > is 'пей', Conv it6-ip).

*j -> t6- (*jẹl 'ветер'> t6il j; *jẹr 'земля’ $>$ t6ir; *jo:1 'дорога' > t6ol);

*š > s/z (*baš 'голова' > pas, Poss3 pazi).

7. Сагайский диалект хакасского языка

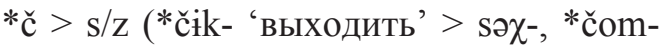
'нырять' > som-; *čo:с̌ka 'свинья' > sos $\chi$; *agač 'дерево' > акаs, Poss1 акаzəm; *sa:č 'волосы' > sas, Poss1 sazəm; *ič- 'пить' > эs 'пей', эzэр деепр.);

*j -> 6- (*jẹl 'ветер'> 6ili ; *jẹr 'земля'> cir; *jo:1 'дорога'> 6ol);

*šs > s/z (*baš 'голова' > pas, Poss 3 pazə).

8. Бельтирский говор сагайского диалекта отличается в данном случае сохранением аффрикатного характера мягкой аффрикаты, северо-восточнее перешедшей в фрикативный:

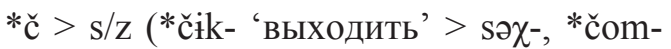

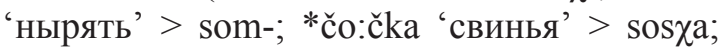
*agač 'дерево' > aвas, Poss1 аваzəm; *sa:č 'волосы' > sas, Poss1 sazəm; *ič- 'пить' > ěs 'пей', е̌zӗр деепр.); 


\begin{abstract}
*j -> t6- (*jẹl 'ветер' > t6il j ; *jẹr 'земля' $>$ t6ir; *jo:l 'дорога' > t6ol);

*`s > s/z (*baš 'голова' > pas, Poss3 pazə).

9. Таштыпский диалект, или «диалект малых деревень». Это идиом, который мы обнаружили в 2016 г., когда работали в поселениях, которые традиционно относятся к шорскому диалекту хакасского языка. В некоторых из них (Верхние Сиры, Малая Сея, Сигиртуп, Шепчул) наблюдается последовательный переход ОТ $*$ с̌ $>$ s, при сохранении ОТ *š. Хакасские диалектологи считают эти говоры «шокающими», принимая сдвиг *с̌ > s за влияние соседнего бельтырского говора. Но строгие соответствия пратюркскому показывают, что это не так:

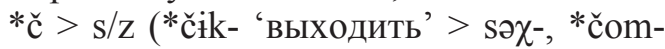

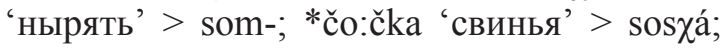
*agač 'дерево' > акаs, Poss1 aьazəm; *sa:č 'волосы' > sas, Poss1 sazəm; *ič- 'пить' > эs 'пей', Conv эzэр);
\end{abstract}

*j -> t6- (*jẹl 'ветер' > tcel; *jẹr 'земля' > tcer; *jo:l 'дорога' > t6ol);

*š > s/z (*bаš 'голова' > pas, Poss3 pazə, *e:šik 'дверь' > izə̨).

Сопоставив все процессы, наблюдаемые в рассмотренных диалектах и говорах, можно выделить следующие генеалогические узлы на их родословном древе (см. схему 1 в приложении):

Мрасский шорский и тутальский сред-

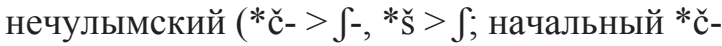
и *ร̌ совпали в одну фонему š);

Кызыльский и мелетский среднечулым-

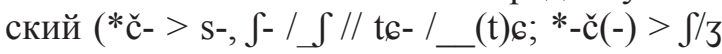
// $\mathrm{s} / \mathrm{z} ; *$ šs $>\mathrm{s})$

Сагайский и бельтирский $\left(* \check{c}>\mathrm{s}, *_{\mathrm{s}}>\mathrm{s}\right.$. Bce $* \check{c}$ и *š совпали с *s в s);

Все «хакасские» диалекты, включая мелетский среднечулымский (*č- > s-).

Кроме того, наблюдается периферийный архаизм хакасского ареала: кызыльский и таштыпский диалекты сохранили оппозицию *č vs *š.

Соответственно, первый распад общего предка - на две ветви, «шорскую» и «хакасскую»; пра-хакасский разделяется на кызыльско-мелетскую ветвь, таштыпский диалект и пра-сагайско-качинскую ветвь, которая потом делится на пракачинский (включающий более архаичный староиюсский) и прасагайский (включающий более архаичный бельтирский). Прашорский распадается на собственно шорский мрасский и несколько более архаичный тутальский чулымский. Существенно, что мелетский и тутальский говоры среднечулымского не образуют общего генеалогического узла, что предполагает заселение нынешней территории их проживания с двух сторон через спуск сверху по Чулыму и через спуск по Мрассу до Томи, оттуда до устья Чулыма и подъем по нему. Географическое распределение диалектов см. на карте 1 в приложении.

2. Тюркские языки Северного Кавказа: диалекты карачаево-балкарского языка

В августе 2018 г. наша группа, при содействии Кабардино-Балкарского научного центра РАН, собирала данные по специализированным опросникам в населенных пунктах Кабардино-Балкарии ${ }^{5}$. Впоследствии работа была распространена 3. К. Айбазовой на Карачаево-Черкесию. Проведенная обработка данных демонстрирует, что можно считать окончательно доказанным, что малкарский говор является результатом осетинского субстратного воздействия на говор хуламо-безенгийского типа (вопреки традиционному мнению, что хуламо-безенгийский представляет собой результат интерференции малкарского и баксано-чегемского).

Рассмотрим распределение рефлексов пратюркского начального *j- в карачаево-балкарских диалектах и их говорах. По классической схеме описания диалектов, к «джокающим» (*j-> dz) относятся два говора - карачаевский и баксанский, к «жокающим» $(* j->$ z) - чегемский и промежуточный хуламо-безенгийский (см., например: [Алиев 1960]). Вместе эти четыре говора составляют опорный диалект, на основе которого разработаны две литературные нормы карачаево-балкарского языка: одна функционирует в Карачаево-Черкесской республике и является «джокающей», другая - в Кабардино-Балкарской республике и является «жокающей». Отметим, что «джокающий» баксанский говор функционирует на территории с «жокающей» литературной нормой, преподающейся в школе. «Зокающий» (*j> z-) диалект представлен преимуществен-

${ }^{5}$ Основные участники экспедиции: 3. К. Айбазова, А. В. Дыбо, Е. В. Коровина, 3. К. Кочакаева, И. А. Невская, А. В. Шеймович. 
но Черекским ущельем и небольшими селами в Лескенском районе Кабардино-Балкарской республики.

Наши данные:

ПТю $*$ j- регулярно дает карач. (все говоры) dz-, баксан. dz-. В баксанских анкетах имеется несколько (около 5 из приблизительно 200 случаев) употреблений твердого 3- в анлауте (только в заднерядных словах). По-видимому, это — результат влияния литературной нормы «балкарского» типа. Регулярное школьное преподавание «балкарской нормы» вкупе с хорошим владением русским языком и совпадением нормативного обозначения балкарского ъ- с русским 3 в ж, по-видимому, приводит к «орфографической интерференции» того типа, которую уже приходилось отмечать в разных регионах проживания тюрков в России, а именно, в говорах, функционирующих на территории «жокающей» балкарской нормы, стремление сказать «на литературном» приводит к произношению 3-. Современное радиовещание на балкарском языке совершенно регулярно использует для рефлекса

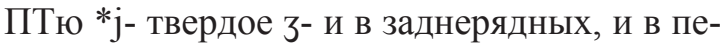
реднерядных словах.

В хуламо-безенгийском говоре, вопреки данным [Алиев 1960; Филоненко 1940; Аппаев 1960], инициальная z- (которая могла бы связать его как смешанный с «зокающим» малкарским диалектом) нам ни разу не встретилась, обычный рефлекс *j- это ъ-. По рассказам местных жителей, в средней части Хуламо-Безенгийского ущелья до войны имелось несколько селений переселенцев из Черекского ущелья, сохранявших зокающий говор, но впоследствии ассимилированных (одно из них - Усхур; возможно, наследием этого говора, соответственно, следом интерференции хуламо-безенгийского с малкарским в отдельном подговоре хуламо-безенгийского является наличие здесь нехарактерного для остальных хуламо-безенгийцев сдвига переднерядных огубленных гласных в средний ряд).

В чегемском говоре также обычный рефлекс *j- это ъ-.

В обоих говорах в заднерядных словах примерно в 38 \% случаев (196 на 516) встречен твердый вариант 3-, причем в старшей возрастной группе он встречается в единичных случаях. В переднерядных словах произношение 3- ни разу не встретилось. По-видимому, это следствие влияния «нормы» в исполнении радиовещания и орфографии.

В обоих «жокающих» говорах достаточно регулярно наблюдается аффрикатный позиционный вариант ъ-, dz- после согласных во фразовой позиции. В хуламо-безенгийском этот вариант практически регулярно выступает после -n предшествующей словоформы:

Ala tilek ${ }^{\mathrm{j}}$ etedīle zawun dzawar ytєy (лит. Ала тилек этедиле жауун жауар ючюн) 'Они молятся о ниспослании дождя’; Ма zariq zanyan dzulduz (лит. Ма жарыкъ жаннган жулдуз) 'Вон яркая звезда'.

В чегемском имеются примеры, где в одном ряду одно и то же слово идет с позиционным z-/ dz- чередованием (аффриката выступает практически регулярно после -n, менее регулярно - после -1, -t, -q):

- Men dzyryjme zolda (лит. Мен жюрюйме жолда) 'Я шагаю по дороге';

- zalin. Ozaq dzalinnan tolкandi. (лит. Жалын. Ожакъ жалындан толгъанды) 'Сажа. В трубе собралось много сажи’;

- Ma bu zïjriq dzafilidi. (лит. Ма бу жыйрыкъ жашилди) 'Вот это платье зеленое';

- Ani zumufaq dzyregi. (лит. Аны жумушакъ жюреги) 'У него доброе сердце'.

Кроме того, в чегемских и хуламо-безенгийских записях регулярно встречается небольшой набор слов, начинающихся на dz- в независимой позиции. В основном это арабские и персидские заимствования: dzanuwar 'зверь', dzur 'косуля', dzin 'бес' (араб.), dzuта 'пятница'; но есть и несколько тюркских: $d z y r e k^{j}$ 'сердце', dzer 'земля', dzastiq 'подушка', dzyzyk 'кольцо', dzafil 'зеленый'. Кажется, опционально действует диссимиляционное правило сохранения аффрикаты перед фрикативным, но так объясняются не все слова. Заимствования из «джокающего» говора?

В «зокающем» (малкарском, черекском) диалекте обычный рефлекс *j- — это z-, слегка палатализующееся в переднерядных словах. Результат влияния радиовещания и графики - примерно 15 \% случаев произношения 3- твердого и в заднерядных, и в переднерядных словах. 
В «зокающем» диалекте регулярно наблюдается аффрикатный позиционный вариант z-, dz- после -n предшествующей словоформы:

- Men dzilikjni syjeme (лит. Мен жиликни сюеме) 'Я люблю костный мозг';

- Sen dzumurtхa syjemse? (лит. Сен жумуртха сюемисе?) 'Ты любишь яйца?'

- Но у той же информантки: Таwuq

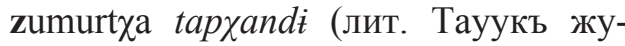
муртха тапханды) 'Курица снесла яйцо'.

Абсолютно тот же набор слов, который встречается с начальной аффрикатой в независимой позиции в хуламо-безенгийских анкетах, здесь присутствует также с аффрикатой, но свистящей, в виде $d z y r e k^{\prime}$, dzer, dzanuwar, dzastiq и т. д. Удивительным образом, в традиционных работах по диалектологии для этих слов в малкарском отмечается «жокающее» произношение, которого мы не обнаружили; правда, в начале Черекского ущелья есть поселения с «жокающим» говором, переселенцы из Хулама.

Такое распределение рефлексов указывает на вторичный характер «зокающего» произношения по отношению к «жокающему». Уже описанное ранее и подтверждаемое нашими материалами распределение «цоканья», т. е. отражения в малкарском ПТ $* \check{c}$, также говорит о вторичности «цокания»: в позиции сандхи перед согласным, как внешних, так и внутренних, старый * не теряет шипящести, но теряет смычку, переходя в $\int: y t s+$ litr 'три литра' $>y \int$ litr, kyts + -lU 'сильный' > kyfly, kyts + zoxtu 'нет сил' > ky zoxtu, yts + -tsIk 'троечка' > yft6yk. Отметим, что наш материал подтверждает точку зрения Ш. Х. Акбаева [Акбаев 1999], в малкарском в сочетании $\int t s$, независимо от его происхождения, второй элемент приобретает шипящую окраску: $y$ ftcyk 'троечка' (yts + -tsIk), beftcik 'пятерочка' (bef + -tsIk), в противоположность мнению Ж. М. Гузеева [Гузеев 1974] (что второй элемент в этих случаях $-t s)$. Объяснение вторичным воздействием осетинского субстрата здесь самое простое.

Потеря смычки начальной звонкой аффрикатой, наоборот, не кажется субстратной и может указывать на существенную общность малкарского, хуламо-безенгий- ского и чегемского говоров. Однако, если посмотреть на географическое распространение этой изоглоссы, мы видим, что это инновационный центральный ареал, в то время как карачаевские и баксанский говоры представляют периферийный подковообразный архаизм (см. карту 2 в приложении). Вопрос о древесном членении карачаево-балкарской общности пока остается открытым.

\section{3. Тюркские языки Урало-Поволжья: татарские и башкирские диалекты}

Для этого региона уже созданы диалектологические атласы [АТНГ 2015; ДАБЯ 2005], рассматриваемому здесь материалу соответствуют карты № 33 из [АТНГ 2015]; № 45-46 из [ДАБЯ 2005]. Кроме опубликованных работ татарских и башкирских диалектологов, ниже использован материал диалектологических опросов, предпринятых в 2017-2020 гг. в основном силами Л. Ф. Абубакировой; по сибирско-татарским диалектам использованы также материалы А. В. Дыбо, В. М. Лемской, Д. М. Токмашева и О. Р. Хисамова. На основании значительного архивного и полевого материала по волгоуральским кыпчакским языкам выясняются новые возможности классификации говоров, границы которой проходят относительно независимо от традиционных социолингвистических границ между языками региона. Оказывается, что не только между диалектами разных волгоуральских языков, но и между диалектами одного языка существует значительная разница в рефлексации начального $*$ j. Традиционное мнение — что различные рефлексы *j- распределены в говорах «беспорядочно» - см., например: [Berta 1989: 197-224]. Реально в материале наблюдается три разных типа «жоканья»: «полное жоканье» (*j- дает шумный согласный при любом последующем контексте), «полное йоканье» $(* j-$ дает глайд при любом последующем контексте) и распределение глайдовых и шумных рефлексов в зависимости от следующего контекста. Разумеется, в полевом материале мы имеем дело также и с различными сдвигами этих систем под влиянием принятых в соответствующих регионах литературных языков, башкирского и татарского. 
Последний тип (далее «татарское распределение») представлен, например, в татарском литературном языке. Это отображение начального *j- как шумного (аффрикаты или фрикатива, условно изображаемого ниже обобщенно как з̆) только в позиции перед старыми неогубленными передними гласными верхнего и среднего подъёма (*i, *e, *e): 亏̌ilem 'клей', 亏̌ir 'земля', з̆іim 'корм', з̌il ‘ветер', з̌il- 'мчаться’, з̌in 'рукав’, з̌ingæ 'жена старшего брата', з̌ik 'злой', з̌імеš 'фрукт', з̌ide 'семь', з̆іz 'медь', 亏̌it- 'достигать', з̌inel 'легкий', క̌imer- 'разрушать', క̌iræn 'рыжий', క̌iznæ 'зять', క̌ilæk 'ягода', క̌ik- 'запрягать', '̌̆iræn- 'брезговать',

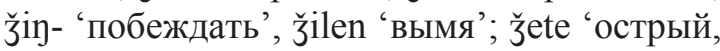
самый', з̌еbe- 'мокнуть', з̌ek 'щель', з̌ер 'нитка'; исключения jegerme 'двадцать', jeget 'молодец' (оба - сложные случаи со специфическим шумным рефлексом срединного -*g- в соседстве с *i в неразложимых основах на пракыпчакском уровне, см. [СИГТЯ 2006: 93, 96]); нерегулярно перед

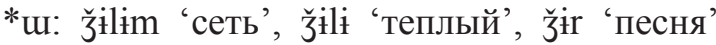
vs jil- 'ползти', jilan 'змея' (*ji:1-), jil 'год' (*jil), jila- 'плакать' (*ji:g-la-), jilqi ‘табунная лошадь’ (*jilki), jiq- 'сбрасывать’ (*jik-); peгулярное отображение *j- как глайда перед всеми другими гласными (јæš 'молодой', jul 'путь', joldiz 'звезда' и т. д.), кроме регулярного же типа исключений: позиция диссимиляции при наличии следующего -j- любого происхождения (в частности, пракыпчакского ј из *-g-): з̌uj- 'разрушать'

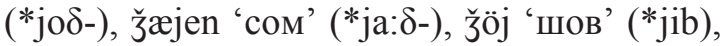
亏̌łj- 'собирать' (*jig-), з̌æj- 'расстилать' (*ja: $\delta$-), з̌æj- 'лето' (*ja:j), з̌ijєn 'племянник' $(*$ jegen $)$.

К сожалению, до сих пор это позиционное распределение не было замечено исследователями, и потому на соответствующих диалектологических картах татарского и башкирского атласов оно отражено весьма опосредованно, хотя, зная о нем, можно по этим картам сделать некоторые выводы о его распространении. Две карты [ДАБЯ 2005], № 45 и 46, построены на распространении йете/жете '7' и йыйын/жыйын 'сом'. Таким образом, они позволяют отличить ситуацию «полного йоканья» от «полного жоканья» и «татарского распределения», но не позволяют различить эти две последних ситуации, так как оба картографированных слова как раз подпадают под условия «жоканья» в этом распределении. Карта № 33, «Ж-оканье в начале собственно татарских слов», в [АТНГ 2015] различает типы 1) «й: йул 'дорога', йир 'земля'...», 2) «ж: жул, жир...», и 3) «й//ж в начале некоторых слов перед гласными ә, е, и» (остальные различия на карте, видимо, представляют собой сбои в отражении *j- и не должны учитываться при анализе). Очевидно, третий тип относится в основном к вышеописанному распределению, если учитывать такие случаи, как з̌æjen 'сом', з̌æj- 'расстилать', з̌æj'лето'.

Изоглосса «татарского распределения» объединяет некоторые мишарские диалекты, литературный и казанский татарский, красноуфимский татарский и айский и аргаяшский диалекты башкирского. Это, по-видимому, результат процесса, проходившего до развития правосточнокыпчакского *æ (ср. отсутствие перехода *j-> 亏̌ перед æ), но после пракыпчакского разбиения рефлексов *-g-. Ареал, охваченный этой изоглоссой, подковообразен, что соответствует по ареалогическим представлениям архаической периферии инновативного процесса. В описании [Максютова 1976: 40-42] утверждается, что «жоканье в айском говоре носит бессистемный характер», но приведенные на стр. 40 и 98 айские и аргаяшские примеры и систематический анализ унаследованной от пратюркского лексики в наших материалах указывают на описанное распределение. Отметим, что при данном типе рефлексации *j- во всех засвидетельствованных случаях как шумный отражается начальный з̆- заимствованной арабской и персидской лексики (క̌an 'душа', з̌оmga 'пятница' и под.)

«Полное йоканье», рефлексация *j- в виде глайда в любой позиции - это наиболее распространенное явление, свойственное всем без исключения сибирско-татарским диалектам (см.: [Алишина

${ }^{6}$ В истории татарской письменности подобную систему могут отражать отступления от стандартной орфографии у Мавля Колыя (середина XVIII в., предположительно Заказанье; ср. ж⿻ле, жуй-, жумарт (из перс. ж⿻ӓва̄нмӓрд [Ахметьянов 2015, 2: 522]) и, возможно, листовки Пугачева, см. [Хисамова 2015: 385-386]; остальные упоминаемые там памятники скорее допускали отступления под влиянием систем полного жоканья. 
2019: 16, 26], эуштинскому, чатскому ${ }^{7}$, барабинскому, тюменскому, тобольскому, вагайскому говорам); части мишарских говоров. Сплошное отражение начального *j- как глайда характеризует также южные и частично восточные (по нашим материалам - миасский и кызыльский) башкирские диалекты. При этом персидские и арабские заимствования на 丂̌-, как и русские заимствования на ж-, в случае адаптации развивают также начальный глайд (башк. йән 'душа' из перс. жа̄н [Ахметьянов 2015, 1: 259] и под.).

Третье явление - переход всех начальных *j- в шумный согласный. Эта черта характеризует собственно среднее наречие татарского (кроме говоров, легших в основу литературного языка), если смотреть на основной ареал его распространения [АТНГ 2015: карта 33]; представлена лишь в нескольких мишарских диалектах, контактирующих с казанско-татарскими. В нашей выборке это явление затрагивает мензелинский и (частично) заказанский диалекты. По всей видимости, этот тип «жоканья» недавняя волго-уральская инновация, на что указывает судьба русских заимствований. Так, в мензелинском рус. јАтА > zрm [ТТЗДС 2009: 179].

Лексикографические данные указывают, что аналогичный тип «жоканья» встречается в бардымском, мамадышском, нагорном, тарханском, нижнекамском камско-устьинском, лаишевском, стерлитамакском говорах; он свойствен всем кряшенским этнолектам (и отражается в орфографии православных богослужебных текстов на татарском языке, см. [Нуриева 2015: 71]), из контактирующих со средним наречием мишарских диалектов - в дрожжановском и этнолекте каратаев [ТТЗДС 2009: 177-182, 190-193].

\footnotetext{
7 Для калмакского - языка телеутов, перешедших на сибирско-татарский чатский и привнесших в него ряд собственных фонетических особенностей - cp. губной сингармонизм на широких гласных, - формально нельзя определить, был ли в исходном татарском говоре $*$ jили *̌̌-, так как в настоящее время там представлен (по крайней мере в части записей) характерный для телеутского и других южно-алтайских диалектов среднеязычный звонкий взрывной [ı]. Но остальные чатские говоры показывают сплошное йоканье.
}

Из описания, изложенного в [Миржанова 1991: 153], нижнебельско-ыкский говор $^{8}$ также характеризуется «полным жоканьем»; наши экспедиционные данные, видимо, подтверждают это, хотя к настоящему времени носители говоров подвергаются сильному воздействию башкирского литературного языка9.

К настоящему времени мы располагаем недостаточными собственными полевыми материалами по проблеме географического распределения типов; к тому же влияние изучаемых в школе и распространяемых СМИ литературных языков за вторую половину XX - начало XXI вв. должно было смазать и, по нашим наблюдениям, несколько смазало картину распределения рефлексов у отдельных носителей идиомов. Тем не менее, сопоставляя построенную по полевым материалам карту (см. карту 3 в приложении) и основанные на более старых (и поэтому, вероятно, менее подвергшихся позднейшим сдвигам) материалах карты [ДАБЯ 2005] и [АТНГ 2015] при учете предложенных выше поправок, можно предположить приблизительно следующую картину.

Для пракыпчакского языкового состояния на месте пратюркского *j- должен восстанавливаться начальный глайд, хотя бы в некоторых позициях (иначе не объясняется позиция диссимилятивного сохранения *-g- при начальном *j-, см. [СИГТЯ 2006: $93,96])$. Но целая картина скорее заставляет предполагать начальную фонему, отличную от глайда, с несколькими позиционными вариантами при разных гласных, дающими впоследствии разнообразные развития. Следы этого разнообразия мы видим, например, в кумыкском (западно-кыпчакском) языке, где наблюдаются пока неясным образом распределенные варианты рефлексов *j- - [j] и [ф]. На общем фоне татаро-башкирского «йоканья» в западной части татаро-башкирской зоны выделяется подковообразный ареал «распределенного йоканья джоканья», который выглядит как архаичный по отношению к продвинувшемуся с

${ }^{8}$ По классификации, принятой в татарской диалектологии - мензелинский говор татарского языка.

${ }^{9}$ По мнению Д. Б. Рамазановой, также нарушения «жоканья» могут быть связаны с влиянием «йокающих» мишарских диалектов [Рамазанова 2020: 94]. 
юга по Волге ареалу «полного джоканья», вероятно, связанному с ранними ногайскими контактами.

\section{Выводы}

Итак, как нам удалось продемонстрировать на рассмотренных примерах, сбор диалектного материала по единообразным

\section{Сокращения}

баксан. - баксанский диалект карачаево-балкарского языка

верхне-июс. - верхнеиюсский говор качинского диалекта хакасского языка

карач. - карачаевский диалект карачаево-балкарского языка

кач. - качинский диалект хакасского языка кыз. - кызыльский диалект хакасского языка мелет. - мелетский говор среднего диалекта

\section{Литература}

Акбаев 1999 - Акбаев Ш. Х. Диалекты карачаево-балкарского языка в структурно-генетическом и ареальном освещении. Карачаевск: Карачаево-Черкес. гос. пед. ун-т, 1999. $257 \mathrm{c}$.

Алиев 1960 - Алиев У. Б. Диалектное членение языка карачаевцев и балкарцев // Третье региональное координационное совещание по вопросам диалектологии тюркских языков. Тезисы докладов. Баку: АН АзССР, 1960. $125 \mathrm{c}$.

Алишина 2019 - Алишина X. Ч. Язык сибирских (тоболо-иртышских) татар. Тюмень: тип. «Печатник», 2019. 198 с.

Аппаев 1960 - Аnпаев A. М. Диалекты балкарского языка в их отношении к литературному балкарскому языку. Нальчик: Кабардино-Балкарское кн. изд-во, 1960. 74 с.

АТНГ 2015 - Атлас татарских народных говоров. Изд. 2-е / Д. Б. Рамазанова, Т. Х. Хайрутдинова (отв. ред.). Казань: ИЯЛИ, 2015. $632 \mathrm{c}$.

Ахметьянов 2015 - Әхмәтьянов Р. Г. Татар теленең этимологик сүзлеге (= Этимологический словарь татарского языка). В 2 т. Казань: Мәгариф - Вакыт, 2015. 543 с.

ДАБЯ 2005 - Диалектологический атлас башкирского языка / отв. ред. Ф. Г. Хисамитдинова. Уфа: Гилем, 2005. 232 с.

Доможаков 1948 - Доможаков Н. Г. Описание кызыльского диалекта хакасского языка: дис. ... канд. филол. наук. Абакан, 1948. $180 \mathrm{c}$.

Дыбо 2007 - Дыбо А. В. Лингвистические контакты ранних тюрков. Лексический фонд. ориентированным на исторический принцип анкетам, с учетом минимальных социолингвистических данных, позволяет сильно уточнить распределение языковых явлений на географической карте и поставить вопросы о соотношении генеалогических и ареальных явлений в истории языка.

чулымского языка

OT - общетюркский язык

ПТ — пратюркский язык

саг. - сагайский диалект хакасского языка

ср.-чулым. - средний диалект чулымскотюркского языка

тутал. - тутальский говор среднего диалекта чулымского языка

хак. шор. - шорский диалект хакасского языка шор. Мp. - мрасский диалект шорского языка

Пратюркский период. М.: Вост. лит., 2007. $222 \mathrm{c}$.

Дыбо и др. 2020а - Дыбо А. В., Мальиева В. С., Николаев С. Л., Шеймович А. В. Диалектологическая анкета для пилотного опроса «Признаки-изоглоссы для хакасско-шорско-чулымского ареала (группы тюркских z-языков)» // Родной язык. 2020. № 1. С. 86-119. DOI: $10.37892 / 2313-5816-2020-1-86-119$

Дыбо и др. $2020 б$ - Дыбо А. В., Кольчикова А. В., Коровина Е. В., Крылова А. С., Лемская В. М., Мальчева В. С., Николаев С. Л., Ренковская Е. А., Султрекова Э. В., Токмашев Д. М., Шеймович А. В. Историческая диалектология тюркских языков “з-группы” (Южная Сибирь). Томск, изд-во ТГУ. 2020 (в печати).

Гузеев 1974 - Гузеев Ж. М. Фонетические особенности малкарского диалекта карачаево-балкарского языка // Советская тюркология. 1974. № 5. С. 62-66.

Максютова 1976 - Максютова Н. Х. Восточный диалект башкирского языка. М.: Наука, 1976. 292 c.

Миржанова 1991 - Миржанова С. Ф. Северо-западный диалект башкирского языка (формирование и современное состояние). Уфа: Башк. кн. изд-во, 1991. 296 с.

Нуриева 2015 - Нуриева Ф. Ш. Диалектная основа книг на «крещено-татарском» языке второй половины XIX века // Урало-алтайские исследования. 2015. № 2. С. 67-73.

Патачакова 1995 - Патачакова Д. Ф. Кызыльский диалект хакасского языка (краткий очерк): пособ. для учителя. Абакан: ХакНИИЯЛИ, 1995. 55 с. 
Рамазанова 2020 - Рамазанова Д. Б. Формирование татарских говоров юго-западной Башкирии. Казань: ИЯЛИ, 2020. 208 с.

СИГТЯ 2002 - Сравнительно-историческая грамматика тюркских языков: Региональные реконструкции / отв. ред. Э. Р. Тенишев. М.: Наука, 2002. 767 с.

СИГТЯ 2006 - Сравнительно-историческая грамматика тюркских языков: Пратюркский язык-основа. Картина мира пратюркского этноса по данным языка / под ред. Э. Р. Тенишева и А. В. Дыбо. М.: Наука, 2006. 912 с.

Сунчугашев, Чебочакова 2013 - Сунчугашев Р. Д., Чебочакова И. М. Об особенностях кызыльского диалекта хакасского языка // Мир науки, культуры, образования. 2013. № 5 (42). С. 338-340.

ТТЗДС 2009 - Татар теленең зур диалектологик сүзлеге (= Большой диалектологический словарь татарского языка) / Ф. Баязитова, Д. Рамазанова, 3. Сайдыкова, Т. Хәйретдинова. Казань: Мәгариф, 2009. 839 с.

Филоненко 1940 - Филоненко В. И. Грамматика балкарского языка. Фонетика и морфология. Нальчик: Кабардино-Балкарское гос. изд-во, 1940. 88 c.

\section{References}

Akbaev Sh. Kh. Karachay-Balkar Dialects: Structural Genetic and Areal Perspectives. Karachayevsk: Karachay-Cherkess State Pedagogical University, 1999. 257 p. (In Russ.)

Akhmetyanov R. G. Etymological Dictionary of the Tatar Language. Vols. 1-2. Kazan: Mägarif Vakyt, 2015. 543 p. (In Tat.)

Aliev U. B. Dialectal segmentation of Karachay-Balkar. In: Turkic Dialectal Studies. Third Regional Coordination Meeting. Theses. Baku: Azerbaijan SSR Academy of Sciences, 1960. 125 p. (In Russ.)

Alishina Kh. Ch. Language of Siberian (Tobol-Irtysh) Tatars. Tyumen: Pechatnik, 2019. 198 p. (In Russ.)

Appaev A. M. Literary Balkar and Its Dialects: A Comparative Perspective. Nalchik: Kabardino-Balkarian Book Publ., 1960. 74 p. (In Russ.)

Aulis J. J. Wörterverzeichnis der Kyzyl-Sprache. Ser.: Studia Orientalia. Vol. XIX(1). Helsinki: Finno-Ugric Society, 1953. 50 p. (In Germ.)

Bayazitova F., Ramazanova D., Saydykova Z., Khayretdinova T. Unabridged Dialectal Dictionary of the Tatar Language. Kazan: Mägarif, 2009. 839 p. (In Tat.)
Хисамова 2015 - Хисамова Ф. М. (ред.) Татар әдәби теле тарихы (XIII гасыр - XX йөз башы) (= История татарского литературного языка (XIII - нач. XX вв.)) / И. Б. Бәширова, Ф. Ш. Нуриева, Э. Х. Кадыйрова. I т. Казан: ТӘһСИ, 2015. Кол-во стр

Berta 1989 - Berta Á. Lautgeschichte der Tatarischen Dialekte // Studia Uralo-Altaica. Vol. 31. Szeged: John Benjamins Pub Co., 1989. $304 \mathrm{~S}$.

Joki 1953 - Joki J. Aulis. Wörterverzeichnis der Kyzyl-Sprache (Studia Orientalia, XIX:1.) Helsinki: Suomalais-ugrilainen seura, 1953. 50 S.

Ringe \& Eska 2013 - Ringe D., Eska J. F. Historical Linguistics: Toward a Twenty-First Century Reintegration (Cambridge Textbooks in Linguistics). Cambridge: Cambridge University Press, 2013. 325 p.

Schönig 1997 - Schönig K. A new attempt to classify the Turkic languages (1) // Turkic languages, 1997, 1, 117-133.

Waibel 2006 - Zinaida Waibel und Andreas Waibel. Der Schor-Dialekt des Chakassischen: Chakassisch oder Schorisch? // In: Marcel Erdal, Irina Nevskaya (eds.) Exploring the Eastern Frontiers of Turkic. Frankfurt: Otto Harrassowitz Verlag, 2006. Pp. 251-264.

Berta Á. Lautgeschichte der Tatarischen Dialekte. Ser.: Studia Uralo-Altaica. Vol. 31. Szeged: John Benjamins Pub Co., 1989. 304 p. (In Germ.)

Domozhakov N. G. A Description of Kyzyl Khakass. Cand. Sc. (philology) thesis. Abakan, 1948. 180 p. (In Russ.)

Dybo A. V. Linguistic Contacts of Early Turks. Vocabulary. Proto-Turkic Period. Moscow: Vostochnaya Literatura, 2007. 222 p. (In Russ.)

Dybo A. V., Kolchikova A. V., Korovina E. V., Krylova A. S., Lemskaya V. M., Maltseva V. S., Nikolaev S. L., Renkovskaya E. A., Sultrekova E. V., Tokmashev D. M., Sheymovich A. V. Turkic Languages of the 'Z'-Group (Southern Siberia): Historical Dialectology. Tomsk: Tomsk State University, 2020 (in press). (In Russ.)

Dybo A. V., Maltseva V. S., Nikolaev S. L., Sheymovich A. V. A dialectological questionnaire for a pilot study on isoglosses in the Turkic "Z" group spoken in the Khakas-Shor-Chulym area. Rodnoy Yazyk. 2020. No. 1. Pp. 86-119. (In Russ.) DOI: 10.37892/2313-5816-2020-186-119

Filonenko V. I. Balkar Grammar: Phonetics and Morphology. Nalchik: Kabardino-Balkarian State Publ. House, 1940. 88 p. (In Russ.) 
Guzeev Zh. M. Malkar dialect of Karachay-Balkar: phonetic features. Sovetskaya tyurkologiya. 1974. No. 5. Pp. 62-66. (In Russ.)

Khisamova F. M. (ed.) History of Literary Tatar: $13^{\text {th }}-$ Early $20^{\text {th }}$ Centuries. I. Bashirova, F. Nurieva, E. Kadiyrova. Vol. I. Kazan: Institute of Language, Literature and History, 2015. (In Tat.)

Maksyutova N. Kh. Eastern Dialect of the Bashkir Language. Moscow: Nauka, 1976. 292 p. (In Russ.)

Khisamitdinova F. G. (ed.). Dialectal Atlas of the Bashkir Language. Ufa: Gilem, 2005. 232 p. (In Bash.)

Mirzhanova S. F. Northwestern Dialect of the Bashkir Language: Origins and Current State. Ufa: Bashkir Book Publ., 1991. 296 p. (In Russ.)

Nurieva F. Sh. The dialectal base of the books written in 'Christened Tatar' in the latter half of the $19^{\text {th }}$ century. Ural-Altaic Studies. 2015. No. 2. Pp. 67-73. (In Russ.)

Patachakova D. F. Kyzyl Khakass: A Brief Essay. Abakan: Khakass Research Institute of Language, Literature and History, 1995. 55 p. (In Russ.)

Ramazanova D. B. The Shaping of Tatar Dialects in Southwest Bashkiria. Kazan: Institute of Language, Literature and History, 2020. 208 p. (In Russ.)

Ramazanova D. B., Khayrutdinova T. Kh. (eds.)
Atlas of Tatar Folk Dialects. $2^{\text {nd }}$ ed. Kazan: Institute of Language, Literature and History, 2015. 632 p. (In Tat. and Russ.)

Ringe D., Eska J. F. Historical Linguistics: Toward a Twenty-First Century Reintegration (Cambridge Textbooks in Linguistics). Cambridge: Cambridge University Press, 2013. 325 p. (In Eng.)

Schönig K. A new attempt to classify the Turkic languages (1). Turkic Languages. 1997. No. 1. Pp. 117-133. (In Eng.)

Sunchugashev R. D., Chebochakova I. M. About peculiarities of the Kyzyl dialect of the Khakass language. The World of Science, Culture and Education. 2013. No. 5 (42). Pp. 338-340. (In Russ.)

Tenishev E. R. (ed.) Comparative Historical Grammar of Turkic Languages: Regional Reconstructions. Moscow: Nauka, 2002. 767 p. (In Russ.)

Tenishev E. R., Dybo A. V. (eds.) Comparative Historical Grammar of Turkic Languages: Proto-Turkic (Ancestor) Language. Worldview of Proto-Turks as Evidenced by Language Data. Moscow: Nauka, 2006. 912 p. (In Russ.)

Waibel Z, Waibel A. Der Schor-Dialekt des Chakassischen: Chakassisch oder Schorisch? In: Erdal M., Nevskaya I. (eds.) Exploring the Eastern Frontiers of Turkic. Frankfurt: Otto Harrassowitz Verlag, 2006. Pp. 251-264. (In Eng.)

Приложение

\section{Генеалогическое древо z-языков Южной Сибири}

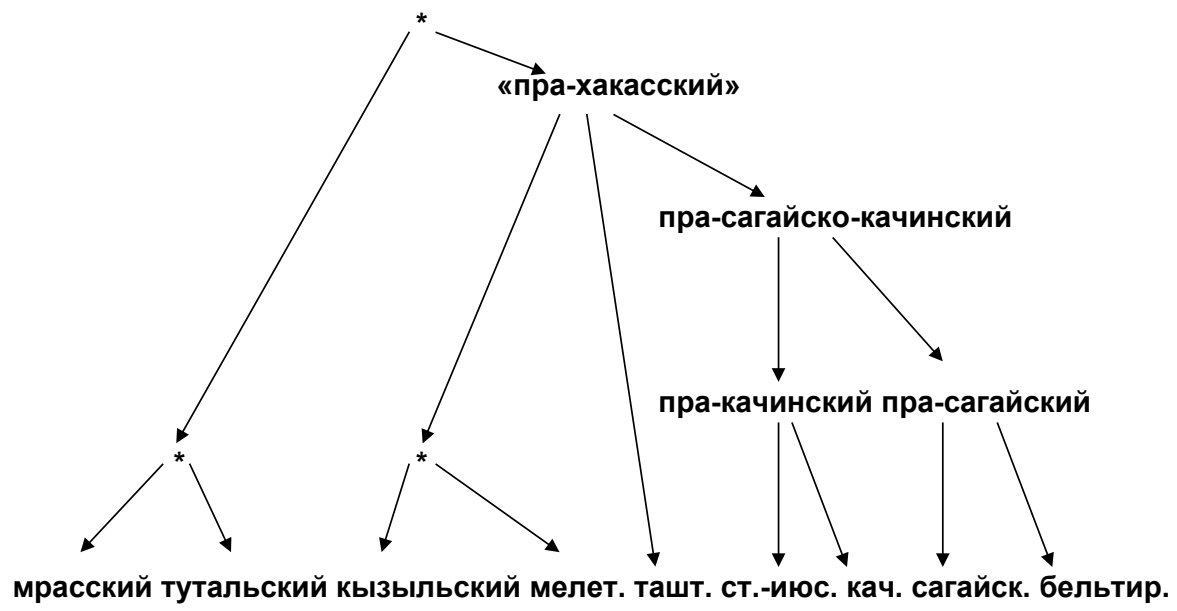

Puc. 1. Генеалогическое древо тюркских з-языков Южной Сибири

[Fig. 1. Genealogical tree of Turkic Z-languages in Southern Siberia] 


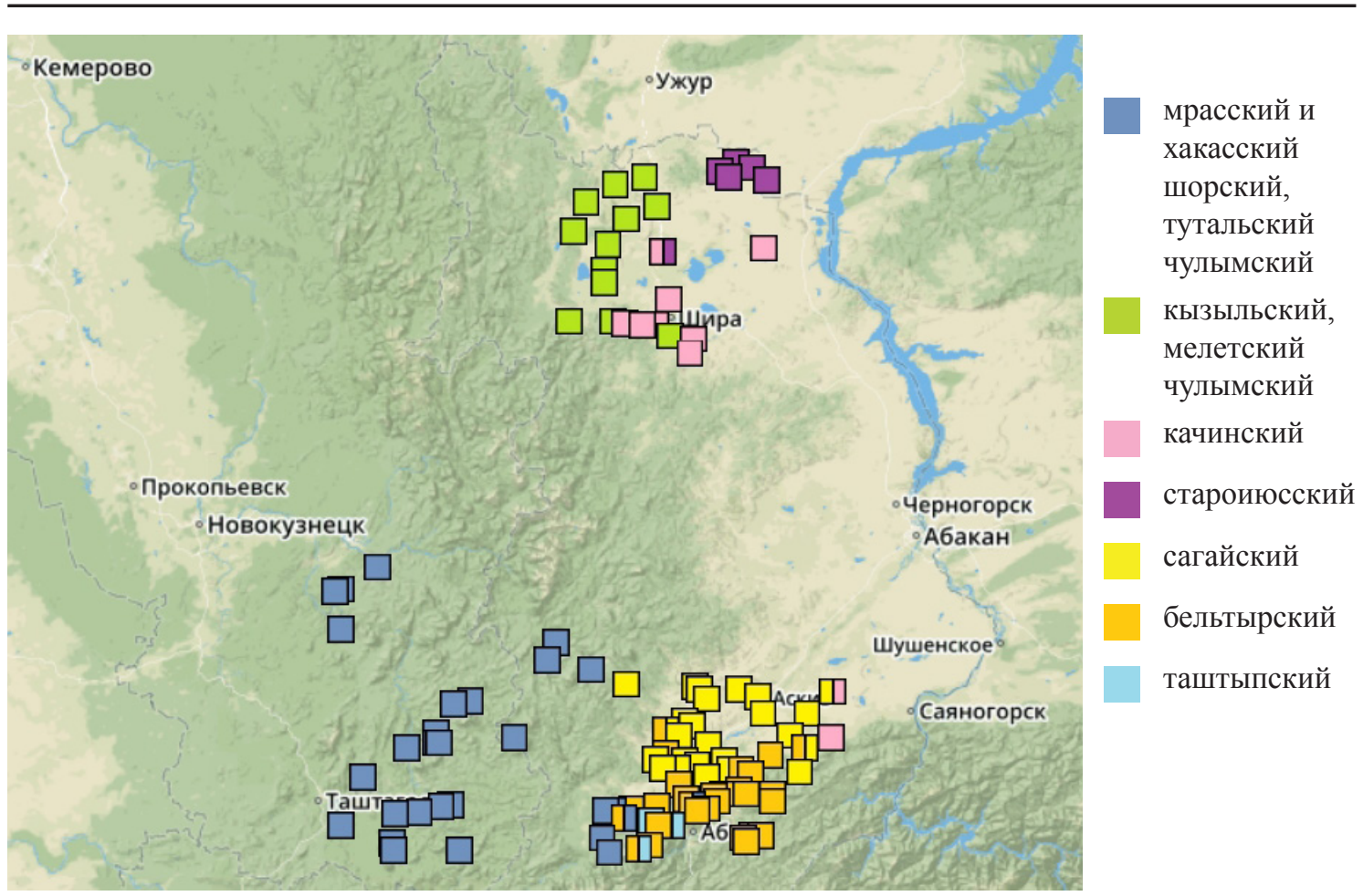

Puc. 2. Карта хакасских и мрасских шорских говоров по данным «аффрикат»

[Fig. 2. Map of Khakass, Mrassu Shor and Middle Chulym sub-dialects according to 'affricate reflexes']

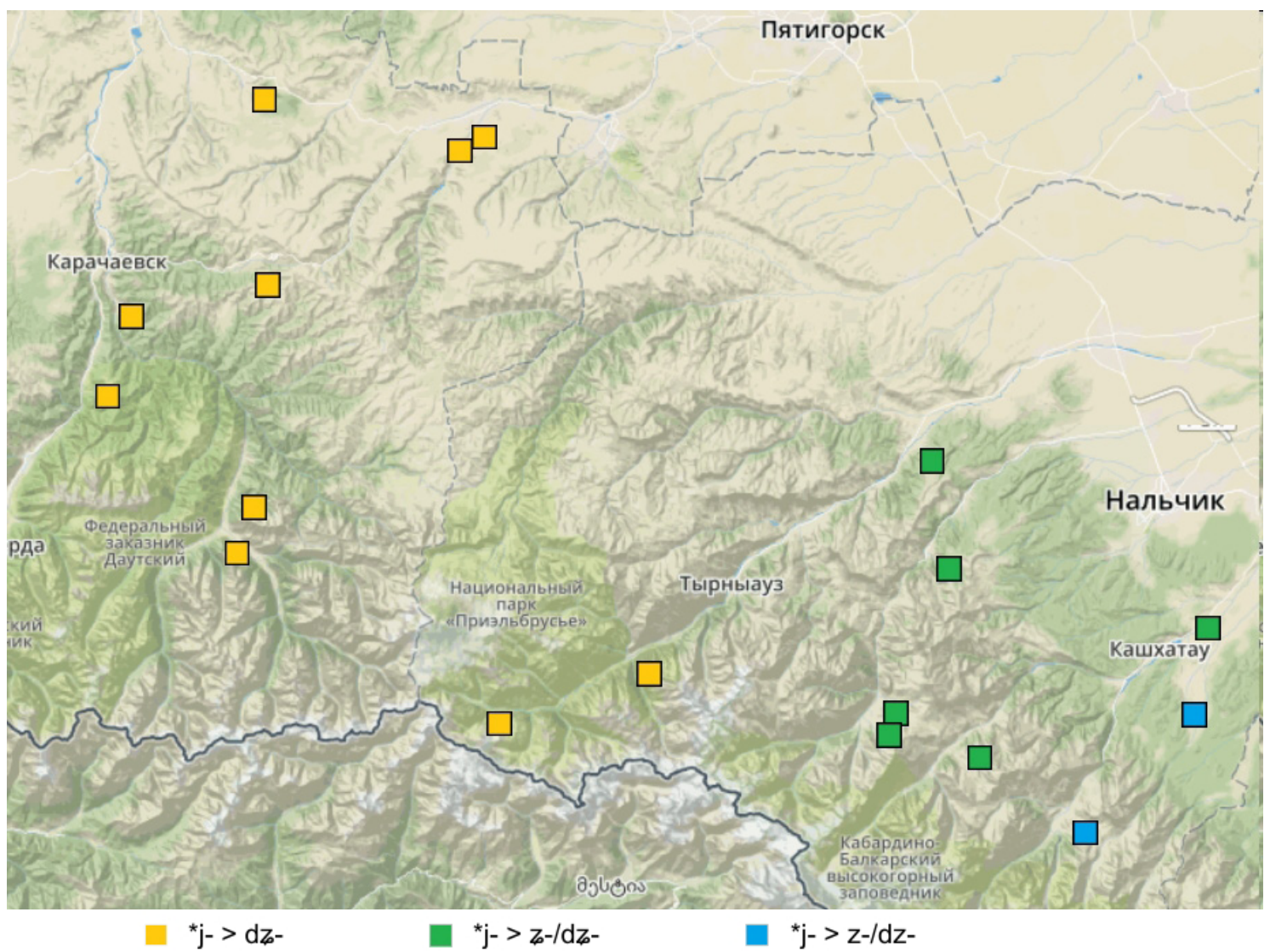

Рис 3. Распространение рефлексов начального *j- в диалектах карачаево-балкарского языка [Fig. 3. Distribution map of reflexes of the initial $*_{j}$ - in Karachay-Balkar dialects] 




